\title{
PENGARUH KOMPETENSI \\ MANAJERIAL KEPALA SEKOLAH DAN BUDAYA KERJA TERHADAP DISIPLIN GURU DI SD ISLAM AL-IKHLAS CIPETE JAKARTA SELATAN
}

\author{
Lia Riyani \\ Program Magister Manajemen Pendidikan Islam \\ Institut PTIQ Jakarta, Indonesia \\ Email : liariyanii@gmail.com
}

\begin{abstract}
This study aims to determine and examine empirical data related to the influence of principals' managerial competencies and work culture on teacher discipline separately or simultaneously. In this study, the authors used a survey method with a correlational and regression approach to the quantitative data obtained from the object of research, namely teachers at SD Islam Al-Ikhlas Cipete South Jakarta. The sample of this study was 66 respondents from 66 populations. The data collection is done by using questionnaire / questionnaire techniques, observation, and documentation. The type of analysis used is the regression analysis which is described descriptively. The results of this study are: 1) There is a positive relationship, which is quite strong and significant between principals' managerial competencies and teacher discipline, which is shown by a simple correlation coefficient (ry.1) is 0.408 (the correlation is quite strong) and the determination coefficient $(R 2)=0.166$, which means that Principal's managerial competence contributes to teacher discipline by $16.6 \%$ and the remaining $84.4 \%$ is determined by other factors. 2) There is a positive relationship, quite strong and significant between work culture and teacher discipline, which is shown by a simple correlation coefficient (ry.2) is 0.321 (the correlation is quite strong) and the determination coefficient (R2) = 0.103 , which means that work culture provides contribution to teacher discipline is $10.3 \%$ and the remaining $89.7 \%$ is determined by other factors. 3) There is a positive, strong and significant relationship between principals' managerial competencies and work culture together with teacher discipline, which is indicated by multiple correlation coefficients (Ry. 1.2) is 0.470 (quite strong correlation) and coefficient of determination $(\mathrm{R} 2)=0.221$, which means that principals' managerial competencies and work culture together contribute to teacher discipline by $22.1 \%$ and the rest $77.9 \%$ is determined by other factors.
\end{abstract}

Kata Kunci : Manajerial Competence, Headmaster, Teacher Discipline. 


\section{Pendahuluan}

Sumber Daya Manusia (SDM) merupakan salah satu faktor yang sangat penting bahkan tidak bisa dilepaskan dari sebuah organisasi, baik perusahaan ataupun instuisi. Sumber Daya Manusia atau pegawai bagi setiap organisasi merupakan aset paling penting yang mengarahkan organisasi, serta mempertahankan dan mengembangkan organisasi dalam berbagai tuntutan masyarakat dan zaman. Guna mencapai tujuan organisasi, diperlukan sumber daya manusia atau pegawai berkualitas yang mampu menyumbangkan segenap daya upaya dalam rangka melayani kebutuhan publik dan memajukan organisasi, sehingga diharapkan mampu memberikan kontribusi berharga bagi instansi. Adapun SDM yang terkait di lingkungan sekolah diantaranya yaitu kepala sekolah dan para guru.

Disiplin guru merupakan nilai-nilai yang menjadi bagian integral dalam suatu organisasi yang harus dimiliki setiap orang yang memiliki pekerjaan, termasuk para guru. Karena bagaimanapun seorang guru merupakan sosok yang ditiru dan digugu oleh setiap siswanya. Disiplin sangat penting untuk pertumbuhan organisasi, digunakan terutama untuk memotivasi para pegawai agar dapat mendisiplinkan diri dalam melaksanakan pekerjaan baik secara perorangan maupun kelompok. Aturan/norma yang ditetapkan suatu lembaga bertujuan agar para guru dapat mematuhi dan melaksanakan peraturan tersebut. ${ }^{1}$ Semakin baik disiplin kerja seorang guru, maka semakin tinggi prestasi kerja yang dapat dicapainya. Tanpa disiplin yang baik dari para guru, sulit bagi sekolah mencapai hasil yang optimal dalam mencetak generasi yang berkualitas, karena disiplin merupakan salah satu faktor yang sangat penting untuk menuju keberhasilan. Dengan disiplin yang baik diharapkan akan

\footnotetext{
${ }^{1}$ Al-Fisqy Kayyasah Amaliyah, "Pengaruh Motivasi Kerja dan Disiplin Kerja Terhadap Kinerja Guru Yayasan Swadhipa Natar TP 2015/2016, Tesis, Bandar Lampung: Pascasarjana Universitas Lampung, 2017
} 
terwujud lingkungan yang tertib, berdaya guna melalui seperangkat peraturan yang jelas dan tepat.

Guru yang disiplin adalah guru yang melaksanakan tugas administrasi, pengelolaan, pengembangan, pengawasan dan pelayanan teknis untuk menjunjung proses pendidikan di sekolah. Disiplin guru juga dapat diartikan sebagai sikap penuh kerelaan atau kesediaan dalam mematuhi semua aturan dan norma yang ada di lingkungan tempat bekerja. Bersedia berarti menunjukan prilaku dan perbuatan untuk melakukan sesuatu dengan kemauan dari diri sendiri tanpa ada paksaan dari orang lain. Umumnya, disiplin ini dapat dilihat dari indikator seperti: guru datang ke tempat kerja tepat waktu, berpakaian rapi, sopan, memperhatikan etika cara berpakaian sebagaimana mestinya seorang guru, mempergunakan alat-alat dan perlengkapan sesuai ketentuan, bekerja penuh semangat, dan bekerja sesuai aturan yang ditetapkan lembaga. Kebiasaan-kebiasaan di atas akan terwujud jika para guru mempunyai disiplin yang baik. Penanaman disiplin di sekolah tentunya perlu diterapkan oleh seorang kepala sekolah terhadap para bawahan yang dipimpinnya terutama para guru untuk menciptakan kualitas kerja yang baik. Melalui disiplin ini diharapkan dapat tercapai tujuan sekolah secara efektif dan efisien, serta dapat meningkatkan produktifitas sekolah.

Di dalam lembaga pendidikan, selain dibutuhkan pemimpin atau kepala sekolah yang kompeten juga perlu adanya penerapan budaya kerja. Budaya atau kultur organisasi merupakan kesepakatan bersama dalam kehidupan organisasi dan mengikat semua organisasi yang bersangkutan. Budaya inilah yang nantinya akan berperan dalam menentukan struktur dan berbagai sistem operasional yang menghasilkan norma-norma, peraturan-peraturan, dan bagaimana interaksi dalam sebuah organisasi. Seorang pemimpin harus mampu mengubah budaya lemah menjadi budaya kuat yang pada akhirnya akan mampu meningkatkan disiplin kinerja bawahan dalam hal ini para guru untuk 
tercapainya tujuan yang telah ditetapkan. Budaya kerja sering kali digunakan dalam melihat keunggulan dan gaya pimpinan dalam menjalankan kegiatan operasional suatu organisasi.

Kegagalan dan keberhasilan suatu organisasi banyak ditentukan oleh pemimpin, karena pemimpin merupakan pengendali dan penentu arah yang hendak ditempuh oleh organisasi menuju tujuan yang akan dicapai. Menurut Tilaar, pemimpin yang profesional bukan hanya menguasai kemampuan dan keterampilan untuk memimpin tapi juga dituntut darinya dua hal, yaitu permimpin yang dapat mengejawantahkan nilai-nilai moral dalam sistem pendidikan, dan juga pemimpin yang memiliki serta menguasai nilai-nilai ilmu pengetahuan dan teknologi sesuai perkembangan zaman. ${ }^{2}$

Kepala sekolah sebagai orang yang menahkodai organisasi dalam suatu lembaga harus mampu mengelola organisasi yang menjadi tanggung jawabnya. Tugas utama pemimpin dalam organisasi yaitu bagaimana pemimpin dapat memberikan arahan, pembagian tugas sesuai dengan kemampuan bawahan dalam bidangnya masing-masing serta dapat memberikan motivasi secara berkesinambungan kepada para bawahan dan yang terpenting adalah dapat menjadi contoh serta suri tauladan bagi para bawahan sehingga tujuan yang telah ditetapkan oleh organisasi tersebut dapat tercapai. Hal ini berarti kepemimpinan tidak hanya dilandasi oleh kemampuan mengatur dan menjalankan mekanisme kepemimpinannya, melainkan menganggap kepemimpinan lebih dilandasi oleh nilai-nilai spiritual, dimana pemimpin dijadikan uswah atau panutan oleh bawahannya.

Disiplin guru sangat berpengaruh kepada karakteristik siswanya karena apabila guru tidak memiliki disiplin yang baik dalam mengajar maka siswa juga akan kurang disiplin dalam belajar, siswa akan mengikuti apa yang dilakukan oleh guru. Guru yang menjalankan dan

2Har Tilaar, Paradigma Baru Pendidikan Nasional, Jakarta: Rineka Cipta, 2000, hal. 159 
mengikuti disiplin dengan baik berarti sudah menjalankan salah satu syarat untuk menjadi guru yang profesional. Sebagaimana hasil uji yang dilakukan pada guru Madrasah Ibtidaiyah Pembangunan UIN Jakarta menunjukkan bahwa faktor kepemimpinan kepala madrasah berpengaruh $13 \%$ terhadap disiplin guru. ${ }^{3}$

Adapun dari hasil pengamatan di SD Islam Al-IKhlas Cipete Jakarta Selatan penulis mendapatkan informasi yang mengindikasikan bahwa disiplin guru belum berjalan secara optimal. Masih terdapat sebagian guru yang terlambat datang ke sekolah ataupun telat masuk ke kelas. Oleh sebab itu penulis tertarik untuk melakukan penelitian dengan judul "Pengaruh Kompetensi Manajerial Kepala Sekolah dan Budaya Kerja Terhadap Disiplin Guru Di SD Islam Al-Ikhlas Cipete Jakarta Selatan"

\section{Kajian Pustaka \\ Disiplin guru}

Disiplin berati ketaatan pada peraturan. ${ }^{4}$ Istilah disiplin berasal dari bahasa Inggris "discipline" yang mengandung beberapa arti, diantaranya adalah pengendalian diri, membentuk karakter yang bermoral, memperbaiki dengan sanksi, serta kumpulan beberapa tata tertib untuk mengatur tingkah laku. ${ }^{5}$ Menurut Siagian, disiplin merupakan "tindakan manajemen untuk mendorong anggota organisasi untuk memenuhi tuntutan berbagai ketentuan." 6 Disiplin juga merupakan kata serapan dari bahasa Belanda "disciplin" atau bahasa latin "disiplina" yang berarti belajar. $^{7}$

\footnotetext{
${ }^{3}$ Nur Hidayah, "Pengaruh Kepemimpinan Kepala Madrasah dan Kecerdasan Emosional Terhadap Disiplin Kerja Guru Di Madrasah Ibtidaiyah Pembangunan UIN Jakarta", Tesis, Jakarta: Pascasarjana Institut PTIQ Jakarta, 2015

${ }^{4}$ Budiono, Kamus Lengkap Bahasa Indonesia, Jakarta: Bintang Indonesia, t.th, hal. 93

${ }^{5}$ Masykur Arif Rahman, Kesalahan-Kesalahan Fatal Paling Sering Dilakukan Guru Dalam Kegiatan Belajar Mengajar, Yogyakarta: Diva Perss, 2011, hal. 64

${ }^{6}$ Sondang P Siagian, Manajemen Sumber Daya Manusia, Jakarta: Bumi Aksara, 2004, hal. 305

7J.S. Badudu, Kamus Kata-kata Serapan Asing dalam Bahasa Indonesia, Jakarta: Kompas, 2003, hal. 65
} 
Disiplin sekolah dapat diartikan sebagai keadaan tertib ketika guru, kepala sekolah dan staf, serta peserta didik yang tergabung dalam sekolah tunduk kepada peraturan yang telah ditetapkan dengan senang hati. ${ }^{8}$ Disiplin merupakan suatu kepatuhan terhadap sebuah peraturan, yang dalam proses pelaksanaannya selalu mengalami proses latihan dan penilaian. Disiplin bagi guru adalah sikap penuh kerelaan dalam mematuhi semua aturan dan norma yang ada dalam menjalankan tugasnya sebagai bentuk tanggung jawabnya terhadap pendidikan. ${ }^{9}$ Dalam bekerja guru dituntut untuk berdisiplin terutama disiplin terhadap waktu dalam kegiatan apapun. Karena sikap disiplin adalah cerminan dari pribadi seseorang yang akan dinilai oleh orang lain. Disiplin kerja guru yang baik mencerminkan besarnya rasa tanggung jawab seorang guru terhadap tugas-tugas yang diberikan kepadanya. Diantara disiplin guru dalam mengajar dapat berupa:

a. Bertanggung jawab atas proses belajar mengajar dan keberhasilan murid; Sebagai tenaga pendidik guru bertangung jawab untuk merencanakan, membimbing dan melaksanakan pembelajaran

b. Berpakaian secara tepat sesuai dengan posisinya sebagai seorang guru; guru harus berpakaian rapi, sopan, tidak berlebihan, serta berpakaian sesuai jadwal yang telah ditentukan. Karena Berpakaian yang sesuai jadwalnya adalah salah satu bentuk latihan disiplin bagi seorang guru

c. Tepat waktu tiba di sekolah dan di kelas; seorang guru harus bisa memanfaatkan waktu sebaik-baiknya, guru yang profesional akan selalu menghargai waktu dan memposisikan waktu sesuai dengan konteks yang dapat diatur oleh dirinya

\footnotetext{
${ }^{8}$ Mulyasa, Implementasi Kurikulum Satuan Pendidikan Kemandirian Guru dan Kepala Sekolah, Jakarta: Remaja Rosdakarya, 2013, hal. 191

9Johanes Purwanto, “Upaya Meningkatkan Disiplin Guru Dalam Kehadiran Mengajar Di Kelas Melalui Reward and Punishment di SDN Bandulan 1 Kecamatan Sukun Malang, " dalam Jurnal Bidang Pendidikan Dasar (JBPD), Vol. 1 No. 2 Tahun 2017, hal. 59
} 
d. Melaksanakan tugas (kegiatan), dalam hal ini memeriksa latihan yang diberikan kepada para siswa, membuat RPP, dan lain sebagainya

e. Program tindak lanjut; seorang guru harus mampu membantu siswa dalam mengalami kesulitan belajar. ${ }^{10}$

Kedisiplinan bagi guru merupakan bagian yang tak terpisahkan dalam melaksanakan tugas dan kewajibannya. Oleh sebab itu tujuan utama disiplin adalah untuk meningkatkan efisiensi semaksimal mungkin dengan cara mencegah pemborosan. Disiplin dibutuhkan untuk tujuan organisasi yang lebih jauh, guna menjaga efisiensi dengan mencegah dan mengoreksi tindakan-tindakan individu dalam sikap tidak baiknya terhadap kelompok. Disiplin perlu diterapkan oleh guru dengan mempertimbangkan konsistensi, rasa saling menghargai, dan juga keadilan. ${ }^{11}$ Menurut Arikunto sebagaimana yang dikutip oleh Darmadi tujuan disiplin yaitu "agar kegiatan sekolah dapat berlangung secara efektif dalam suasana tenang, tentram dan setiap guru beserta karyawan dalam organisasi sekolah merasa puas karena terpenuhi kebutuhannya."12 Dengan kata lain tujuan adanya disiplin adalah untuk melatih para guru patuh dan taat terhadap peraturan sehingga dapat membantu lancarnya proses pendidikan.

Kemampuan kepala sekolah dalam menanamkan disiplin kepada para guru merupakan bagian dari kompetensi kepala sekolah itu sendiri. Dengan demikian diduga terdapat pengaruh kompetensi manajerial kepala sekolah terhadap disiplin guru.

Keberhasilan tujuan pendidikan terutama di sekolah dipengaruhi oleh beberapa faktor diantaranya faktor guru dan tenaga pendidik di lingkungan sekolah. Menegakkan disiplin tidak harus melibatkan orang

\footnotetext{
${ }^{10}$ Ellys Tjo, Kompetensi Guru-guru Efektif, Jakarta : Permata Puri Media, 2013, hal. 146 147.

${ }^{11}$ Lara Fridani, Inspiring Education-Usia Sd (True Storie), Jakarta: PT. Elex Media Komputindo, 2013, hal. 131

${ }^{12}$ Darmadi, Membangun Paradigma Baru Kinerja Guru, Bogor: Guepedia Publisher, t.th, hal. 60
} 
lain, tetapi dapat juga melibatkan diri sendiri. Bahkan yang melibatkan diri sendiri ini jauh lebih penting karena timbul dari kesadaran diri sendiri. Disiplin guru sangat beragam seperti disiplin dalam kehadiran, disiplin guru dalam bidang perencanaan pembelajaran, disiplin guru dalam kegiatan belajar mengajar, disiplin guru dalam meningkatkan evaluasi pembelajaran. Adapun menurut handoko dapat dirumuskan tiga pendekatan disiplin, yaitu:

a. Disiplin preventif, mengatur untuk mencegah agar tidak terjadi pelanggaran selanjutnya

b. Disiplin punitif, yang disebut disiplin negatif, yaitu memberi rasa takut

c. Disiplin positif, yaitu filosofi manajemen, perbaikan prilaku karyawan yang bisa diterapkan dalam jangka panjang ${ }^{13}$

Allah berfirman dalam QS an-Nisa/4:59

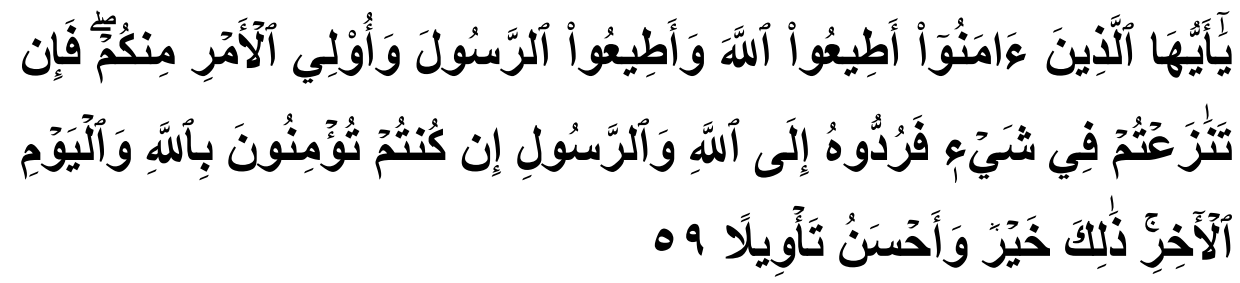

Hai orang-orang yang beriman, taatilah Allah dan taatilah Rasul (Nya), dan ulil amri di antara kamu. Kemudian jika kamu berlainan pendapat tentang sesuatu, maka kembalikanlah ia kepada Allah (Al Quran) dan Rasul (sunnahnya), jika kamu benar-benar beriman kepada Allah dan hari kemudian. Yang demikian itu lebih utama (bagimu) dan lebih baik akibatnya (an-Nisa' / 4:59)

Dari ayat diatas dijelaskan bahwa islam memberi tuntunan dalam menjalankan pekerjaan untuk patuh terhadap pemimpin. Dan tentunya patuh kepada seorang pemimpin dalam perkara kebaikan bukan kemungkaran.

\section{Kompetensi Manajerial Kepala Sekolah}

\footnotetext{
${ }^{13}$ Isyandi et.al,"Pengaruh kepemimpinan, Budaya Kerja, Lingkungan Kerja Terhadap Disiplin Kerja dan Kinerja Personil Polda Riau," dalam Jurnal Tepak Manajemen Bisnis, Vol. 06 No. 02 Tahun 2014, hal. 10
} 
Menurut Sudarwan Danim, ada lima kompetensi yang harus dimiliki oleh kepala sekolah, yaitu:
a. Memahami visi organisasi dan memiliki visi kerja yang keras
b. Mampu dan mau bekerja keras
c. Tekun dan tabah dalam bekerja dengan bawahan
d. Memberikan layanan yang optimal dengan tetap rendah hati
e. Memiliki disiplin kerja yang kuat ${ }^{14}$

Selain dari lima kompetensi di atas, Jamal Ma'mur Asmani menambahkan ada tujuh kompetensi yang harus dimiliki oleh seorang kepala sekolah dalam mengemban tugasnya. Tujuh kompetensi tersebut adalah:

a. Kompetensi kepribadian,

b. Kompetensi manajerial,

c. Kompetensi kewirausahaan,

d. Kompetensi supervisi,

e. Kompetensi sosial.

f. Kompetensi pemikiran,

g. Kompetensi spiritual. ${ }^{15}$

Adapun tugas kepala sekolah dalam menjalankan kompetensi manajerial meliputi:

a. Kemampuan menyusun perencanaan sekolah untuk berbagai tingkatan

b. Kemampuan mengembangkan organisasi sekolah sesuai kebutuhan

c. Kemampuan mengembangkan aneka ragam organisasi informal sekolah, seperti membangun kerjasama tim dalam membangun sekolah

\footnotetext{
${ }^{14}$ Sudarwan Danim, Visi Baru Manajemen Sekolah: Dari Unit Birokrasi ke Lembaga Akademik, Jakarta: Bumi Aksara, 2007, cet. 2, hal. 56

${ }^{15}$ Jamal Ma'mur Asmani, Tips Menjadi Kepala Sekolah Profesional, Yogyakarta: Diva Press, Cetakan 1, 2012, hal. 22.
} 
d. Kemampuan mengelola guru dan staf dalam rangka pendayagunaan SDM secara optimal

e. Kemampuaan mengelola sarana dan prasarana sekolah ${ }^{16}$

Salah satu fungsi manajerial adalah melakukan perencanaan. Sebagai pemimpin kepala sekolah harus menjaga kualitas sekolah atau madrasah agar tetap relevan dengan kondisi tuntutan kemajuan zaman. Karena sesuatu yang telah direncanakan dianggap dapat mencapai hasil yang diinginkan. Oleh sebab itu kompetensi manajerial sangat penting dimiliki oleh kepala sekolah dalam mengembankan tanggung jawabnya dalam suatu organisasi.

Istilah manajemen merupakan kata sifat yang berhubungan dengan kepemimpinan dan pengelolaan. Manajemen juga mengacu kepada proses pelaksanaan aktivitas yang diselesaikan secara efisien dengan pendayagunaan orang lain. ${ }^{17}$ Manajemen merupakan suatu proses merencanakan, mengorganisasikan, menggerakkan dan mengendalikan sebagai suatu usaha dalam pendayagunaan seluruh sumber daya untuk mencapai tujuan secara efektif dan efisien. Manajemen dalam pelaksanaan program pendidikan bukanlah tujuan, melainkan alat atau metode untuk mencapai mutu dan meningkatkan performance yang di harapkan. ${ }^{18}$

التببيز Dalam pandangan Islam, manajemen diistilahkan dengan kata (pengaturan). ${ }^{19}$ Kata ini merupakan derivasi dari دبر (mengatur). Hal ini sesuai dengan firman Allah yang tercantum dalam QS as-Sajdah/32:5 sebagai berikut:

\footnotetext{
${ }^{16}$ Doni Juni Priansa dan Rismi Somad, Manajemen Supervisi dan Kepemimpinan Kepala Sekolah, Bandung : Alfabeta, 2014, h. 58

${ }^{17}$ Mariono et.al, Manajemen dan Kepemimpinan Pendidikan Islam, Bandung: PT Refika Aditama, 2008, hal. 1

18Mohamad Mustari, Manajemen Pendidikan, Jakarta: PT. Raja Grafindo Persada, 2015, hal. 2

${ }^{19}$ Ramayulis, Ilmu Pendidikan Islam, Jakarta: Kalam Mulia, 2008, hal. 362
} 


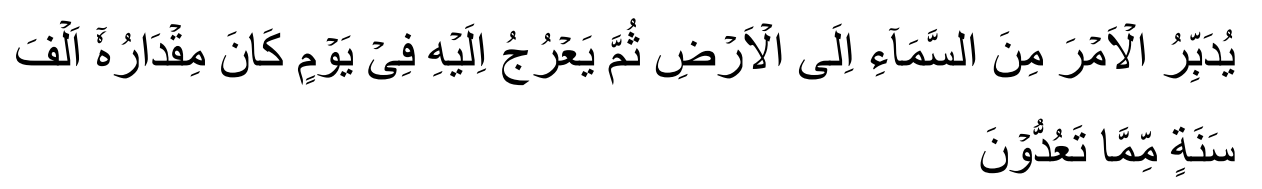

Dia mengatur urusan dari langit ke bumi, kemudian (urusan) itu naik kepadanya dalam satu hari yang kadarnya adalah seribu tahun menurut perhitunganmu (as-Sajdah/32:5)

Dari isi kandungan ayat di atas dapat diketahui bahwa Allah SWT adalah pengatur alam (manajer). Keteraturan alam raya ini merupakan bukti kebesaran Allah SWT dalam mengelola alam ini. Namun, karena manusia yang diciptakan Allah SWT telah dijadikan sebagai khalifah di bumi, maka manusialah yang harus mengatur dan mengelola bumi dengan sebaik-baiknya sebagaimana Allah mengatur alam raya ini.

Konsep manajemen yang diajarkan dalam Islam yaitu kebenaran, kejujuran, keterbukaan dan keahlian. Seorang manajer harus memiliki keempat sifat tersebut agar manajemen yang dijalankannya mendapatkan hasil yang maksimal. ${ }^{20}$ Sedangkan manajerial merupakan kata sifat yang berhubungan dengan kepemimpinan dan kepengelolaanManajemen merupakan kata benda yang dapat berarti pengelolaan, tata pimpinan atau ketatalaksanaan. ${ }^{21}$

Menurut Poerwodarminto "Manajerial berasal dari kata manajer yang berarti orang yang menjadi pimpinan atau orang yag mengatur jadwal, membuat rencana."22 Kompetensi manajerial juga berarti kemampuan yang mendalam mengenai urusan kepemimpinan melalui keahlian yang spesifik sehingga dapat mencapai tujuan pendidikan yang efektif dan efisien.

\footnotetext{
${ }^{20} Z$ Zainarti, “Manajemen Islam Perspektif Al-Qur'an," dalam Jurnal Iqra', Vol. 08 No. 01 Tahun 2014, hal. 49

${ }^{21}$ Ulbert Silalahi, Studi tentang Ilmu Administrasi, Bandung: Sinar Baru Algensindo, 2002, hal. 135

${ }^{22}$ W. J. S Poerwodarminto, Kamus Umum Bahasa Indonesia, jakarta: Balai Pustaka, 2006, hal. 742
} 


\section{Budaya Kerja}

Budaya kerja pada umumnya merupakan pernyataan filosofis, dapat difungsikan sebagai tuntutan yang mengikat para guru karena dapat dijadikan sebagai peraturan dan ketentuan-ketentuan yang diterapkan di sekolah. Budaya kerja memiliki peran yang sangat besar dalam memberikan stimulasi terhadap karyawan untuk bekerja dan menjalankan tugas-tugas tertentu dalam pencapaian kinerja pekerjaan. Budaya kerja berupaya mengubah komunikasi tradisional menjadi perilaku manajemen modern, sehingga tertanam kepercayaan dan semangat kerjasama yang tinggi serta disiplin. Budaya kerja yang kuat akan berpengaruh positif pada prilaku kerja karena dapat memberikan motivasi luar biasa pada karyawan untuk mencapai kinerja yang maksimal. Budaya kerja kerja diturunkan dari budaya organisasi, karena budaya itu sendiri berkembang sesuai dengan tujuan masing-masing organisasi. Adapun dalam kaitannya dengan dunia pendidikan di sekolah, maka bahwa budaya kerja adalah kebiasaan, tradisi yang dilakukan oleh guru dalam melaksanakan tugas atau kewajibannya.

Menurut Dewi, budaya kerja yang baik memberikan beberapa manfaat, diantaranya adalah:

a. Memelihara lingkungan kerja yang serasi serta harmonis

b. Menciptakan kondisi kerja yang teratur

c. Menciptakan kondisi kerja yang tertib dan aman

d. Memastikan pelaksanaan hak dan kewajiban kerja

e. Memakmurkan dan mensejahterakan pekerja

f. Meningkatkan etos kerja yang tinggi dan dinamis ${ }^{23}$

Dari pemaparan di atas dapat diambil kesimpulan bahwa budaya kerja sangat penting diterapkan dalam suatu organisasi demi tujuan yang efektif dan efisien. Oleh karena itu, setiap guru sebagai pendidik harus

\footnotetext{
${ }^{23}$ Rina Puspita Dewi, Modul: Menjaga dan Melindungi Budaya Kerja Sesuai Standar Isi 2006, Jakarta: Yudhistira, t.th, hal. 4
} 
mengikuti budaya yang ada di lingkungan tempat ia bekerja dalam hal ini di sekolah agar dapat melaksankan tugas atau bekerja dengan efektif dan efisien.

\section{Metode Penelitian}

Metode yang digunakan dalam penelitian ini adalah metode survai dengan pendekatan korelasional. Metode survai dipergunakan dengan pertimbangan-pertimbangan bahwa penelitian dilakukan untuk mendapatkan data setiap variabel masalah penelitian dari tempat tertentu yang alamiah (bukan buatan) dengan alat pengumpul data berbentuk angket (kuesioner), test dan wawancara terstruktur dan berdasarkan pandangan dari sumber data, bukan dari peneliti.

Dalam penelitian ini, subjek yang diteliti sebagai sumber data atau responden adalah guru di SD Islam Al-Ikhlas Cipete Jakarta Selatan. Adapun teknik untuk menentukan guru sebagai sampel dalam penelitian ini peneliti menggunakan teknik Sampel jenuh, yaitu menjadikan seluruh anggota populasi sebagai sampel penelitian. Adapun untuk mengukur ukuran sampel dari populasinya, penelitian ini mengacu pada pendapat Gay sebagaimana dikutip oleh Soegoto yang menyatakan bahwa jika penelitiannya bersifat deskriptif, maka sampel minimunya adalah 10\% dari populasi, jika penelitianya korelasional, sampel minimunya adalah 30 subjek. Apabila penelitian kausal perbandingan, sampelnya sebanyak 30 subjek per group dan apabila penelitian eksperimental, sampel minimumnya adalah 15 subjek per group. ${ }^{24}$ Berdasarkan uraian di atas, maka penelitian ini termasuk ke dalam penelitian korelasional dengan minimal 30 subyek untuk dijadikan populasi. Dengan demikian, jumlah sampel dalam penelitian ini adalah 66 orang guru di SD Islam Al-Ikhlas Cipete Jakarta Selatan.

\footnotetext{
${ }^{24}$ Eddy Soeryanto Soegoto, Marketing Reserch (The Smart Way to Solve a Problem), Jakarta: Elex Media Komputindo, 2008, hal. 106
} 
Variabel dalam penelitian ini meliputi tiga variabel penelitian yaitu variabel terikat Disiplin Guru (Y), variabel bebas Kompetensi Manajerial Kepala Sekolah $\left(X_{1}\right)$, variabel bebas Budaya Kerja $\left(X_{2}\right)$. Adapun skala pengukurannya menggunakan skala Likert dalam bentuk angket dengan lima alternatif jawaban.

Penskoran instrumen yang berupa angket (kuesioner) untuk variabel $\mathrm{Y}$, dan $\mathrm{X}_{2}$ menggunakan lima pilihan bertingkat (rating scale), yaitu untuk pernyataan bersifat positif, maka responden yang menjawab sangat setuju (SS) mendapat skor 5, setuju (S) mendapat skor 4, kurang setuju (KS) mendapat skor 3, tidak setuju (TS) mendapat skor 2, dan sangat tidak setuju (STS) mendapat skor 1.

Teknik pengumpulan data dalam penelitian ini menggunakan teknik penyebaran quesioner atau angket untuk mendapatkan data yang bersifat pendapat atau persepsi dari sumber data.

Terdapat dua macam analisis/statistik yang digunakan untuk menganalisis data dalam penelitian, yaitu analisis/statistik deskriptif dan analisis/statistik inferensial. Analisis/statistik inferensial terdiri dari dua bagian yaitu statistik parametrik dan statistik nonparametrik. ${ }^{25}$

Analisis deskriptif adalah analisis yang digunakan untuk menganalisis data dengan cara mendeskripsikan atau menggambarkan data yang telah terkumpul sebagaimana adanya tanpa bermaksud membuat kesimpulan yang berlaku umum atau generalisasi. Analisis deskriptif merupakan proses pengumpulan data sampai dengan penyajian. ${ }^{26}$ Analisis deskriptif bertujuan untuk menggambarkan atau mendeskripsikan informasi yang diperoleh. Untuk menjawab rumusan masalah, pertama digunakan analisis prosentase, deskripsi ini digunakan untuk mengetahui gambaran kompetensi manajerial kepala sekolah,

\footnotetext{
${ }^{25}$ Sugiyono, Metode Penelitian Pendidikan Pendekatan Kuantitatif, Kualitatif, dan $R \mathcal{E} D$, Bandung: Alfabeta. 2013, h.207

${ }^{26}$ Nia Sari dan Ratna Wardani, Pengolahan dan Analisis Data Statistika dengan SPSS, Yogyakarta: Deepublish, 2015, hal. 57
} 
budaya kerja, dan disiplin guru di SD Islam Al-Ikhlas Cipete Jakarta Selatan.

Analisis inferensial merupakan cara menganalisis data serta mengambil kesimpulan berkaitan dengan estimasi parameter dan pengujian hipotesis. ${ }^{27}$ Analisis inferensial sering juga disebut analisis induktif yang digunakan untuk menganalisis data sampel dan hasilnya akan digeneralisasikan atau disimpulkan untuk populasi dari asal sampel itu diambil. ${ }^{28}$ Analisis inferensial digunakan untuk sampel yang diambil dari populasi dengan teknik pengambilan sampel secara random.

Analisis inferensial ini disebut juga analisis probabilitas, karena kesimpulan yang diberlakukan untuk populasi berdasarkan data sampel yang kebenarannya bersifat peluang (probability). Suatu kesimpulan dari data sampel yang akan diberlakukan untuk populasi mempunyai peluang kesalahan dan kebenaran (kepercayaan) yang dinyatakan dalam bentuk prosentase. Bila peluang kesalahan 5\%, maka taraf kepercayaan 95\% dan bila peluang kesalahan 1\%, maka taraf kepercayaan 99\%. Peluang kesalahan dan kepercayaan ini disebut dengan istilah "taraf signifikansi". Dalam statistika inferensia diadakan pendugaan parameter, membuat hipotesis, serta menguji hipotesis tersebut sampai pada pembuatan kesimpulan yang berlaku secara umum. Dalam metode ini, kesimpulan yang ditarik didasarkan pada informasi dari sebagian data saja.

\section{Hasil pembahasan}

Untuk membuktikannya, maka penelitian ini mengajukan tiga hipotesis yang pembuktiannya perlu diuji secara empirik. Ketiga hipotesis tersebut adalah merupakan dugaan sementara tentang pengaruh kompetensi manajerial kepala sekolah $\left(X_{1}\right)$, budaya kerja $\left(X_{2}\right)$ baik secara sendiri-sendiri maupun secara bersama-sama terhadap disiplin guru (Y).

\footnotetext{
${ }^{27}$ M. Muchson, Statistik Deskriptif, Tuban: Spasi Media, t.th, hal. 7

28 Yeri Sutopo dan Achmad Slamet, Statistika Inferensial, Yogyakarta: Penerbit ANDI, tt, hal. 2
} 
Oleh karena itu, di bawah ini secara lebih rinci masing-masing hipotesis akan diuji sebagai berikut:

1. Pengaruh kompetensi manajerial kepala sekolah $\left(\mathrm{X}_{1}\right)$ terhadap disiplin guru $(\mathrm{Y})$

Ho: $\rho_{\mathrm{y} 1}=0$ artinya tidak terdapat pengaruh positif dan signifikan kompetensi manajerial kepala sekolah $\left(\mathrm{X}_{1}\right)$ terhadap disiplin guru $(\mathrm{Y}) .\left(\mathrm{X}_{1----} \mathrm{Y}\right)$

$\mathrm{Hi}: \rho_{\mathrm{y} 1}>0$ artinya terdapat pengaruh positif dan signifikan kompetensi manajerial kepala sekolah $\left(X_{1}\right)$ terhadap disiplin guru (Y). $\quad\left(\mathrm{X}_{1----Y)}\right.$

Tabe1 1. Kekuatan Pengaruh (Koefisien Korelasi Sederhana) $\left(\rho_{y 1}\right)$

Correlations

\begin{tabular}{|c|c|c|c|}
\hline & & $\begin{array}{l}\text { Disiplin } \\
\text { Guru }\end{array}$ & $\begin{array}{l}\text { Kompetensi } \\
\text { Manajerial Kepala } \\
\text { Sekolah }\end{array}$ \\
\hline $\begin{array}{l}\text { Disiplin Guru } \\
\text { Kompetensi } \\
\text { Manajerial } \\
\text { Kepala Sekolah }\end{array}$ & $\begin{array}{l}\text { Pearson } \\
\text { Correlation } \\
\text { Sig. (2-tailed) } \\
\mathrm{N} \\
\text { Pearson } \\
\text { Correlation } \\
\text { Sig. (2-tailed) } \\
\mathrm{N}\end{array}$ & $\begin{array}{l}1 \\
66 \\
608^{* *} \\
, 001 \\
66\end{array}$ & $\begin{array}{l}, 408^{* *} \\
, 001 \\
66 \\
1 \\
\\
66\end{array}$ \\
\hline
\end{tabular}

**. Correlation is significant at the 0.01 level (2-tailed).

Keterangan: Interpretasi atau kriteria derajat koefisien korelasi:

0 : Tidak ada korelasi atau tidak ada hubungan

0,10-0,25 : Korelasi atau hubungan lemah

0,26-0,50 : Korelasi atau hubungan cukup kuat

0,51-0,75 : Korelasi atau hubungan kuat

0,76-0,99 : Korelasi atau hubungan sangat kuat

: Korelasi atau hubungan sempurna 
Berdasarkan tabel 1 tentang pengujian hipotesis $\rho_{y 1}$ di atas, menunjukkan bahwa pada tingkat kepercayaan 99\% $(\alpha=0,01)$ diperoleh koefisien korelasi sederhana Pearson correlation $\left(\rho_{\mathrm{y} 1}\right)$ adalah 0,408 dan nilai signifikansi adalah 0,001<0,05. Dengan demikian, maka Ho ditolak dan Hi diterima, yang berarti bahwa terdapat pengaruh positif yang cukup kuat dan signifikan kompetensi manajerial kepala sekolah terhadap disiplin guru.

Tabel 2. Besarnya Pengaruh (Koefisien Determinasi) $\left(\rho_{\mathrm{y} 1}\right)$ Model Summary ${ }^{\mathrm{b}}$

\begin{tabular}{|l|l|l|lr|l|}
\hline Model & R & R Square & $\begin{array}{l}\text { Adjusted } \\
\text { Square }\end{array}$ & Std. Error of the Estimate \\
\hline 1 &, $408^{\mathrm{a}}$ &, 166 &, 153 & 9,691 \\
\hline
\end{tabular}

a. Predictors: (Constant), Kompetensi Manajerial Kepala Sekolah

b. Dependent Variable: Disiplin Guru

Adapun besarnya pengaruh ditunjukkan oleh koefisien determinasi $\mathrm{R}^{2}(\mathrm{R}$ square $)=0,166$, yang berarti bahwa kompetensi manajerial kepala sekolah memberikan pengaruh terhadap disiplin guru sebesar 16,6\% dan sisanya yaitu 84,4\% ditentukan oleh faktor lainnya.

Adapun arah pengaruh atau koefisien regresi sederhana disiplin guru atas kompetensi manajerial kepala sekolah, adalah sebagai berikut: 
Tabel 3. Arah Pengaruh (Koefisien Regresi Sederhana) $\left(\rho_{\mathrm{y} 1}\right)$ Coefficients ${ }^{\mathrm{a}}$

\begin{tabular}{|c|c|c|c|c|c|c|}
\hline \multirow[t]{2}{*}{ Model } & & \multicolumn{2}{|c|}{$\begin{array}{l}\text { Unstandardized } \\
\text { Coefficients }\end{array}$} & \multirow{2}{*}{\begin{tabular}{|l}
$\begin{array}{l}\text { Standardize } \\
\mathrm{d} \\
\text { Coefficients }\end{array}$ \\
Beta
\end{tabular}} & \multirow[t]{2}{*}{$t$} & \multirow[t]{2}{*}{ Sig. } \\
\hline & & B & \begin{tabular}{|l} 
Std. \\
Error
\end{tabular} & & & \\
\hline 1 & $\begin{array}{l}\text { (Constant) } \\
\text { Kompetens } \\
\text { i Manajerial } \\
\text { Kepala } \\
\text { Sekolah }\end{array}$ & $\begin{array}{l}84,035 \\
, 265\end{array}$ & $\begin{array}{l}9,796 \\
, 074\end{array}$ & , 408 & $\begin{array}{l}8,579 \\
3,571\end{array}$ & $\begin{array}{l}, 000 \\
, 001\end{array}$ \\
\hline
\end{tabular}

a. Dependent Variable: Disiplin Guru

Memperhatikan hasil analisis regresi sederhana pada tabel di atas, menunjukkan persamaan regresi sederhana (unstandardized coefficients B) $\hat{Y}=84,035+0,265 X_{1}$ yang berarti bahwa setiap peningkatan satu unit skor kompetensi manajerial kepala sekolah akan mempengaruhi peningkatan skor disiplin guru sebesar 0,265. Adapun diagram pencar untuk persamaan regresi tersebut adalahsebagai berikut:

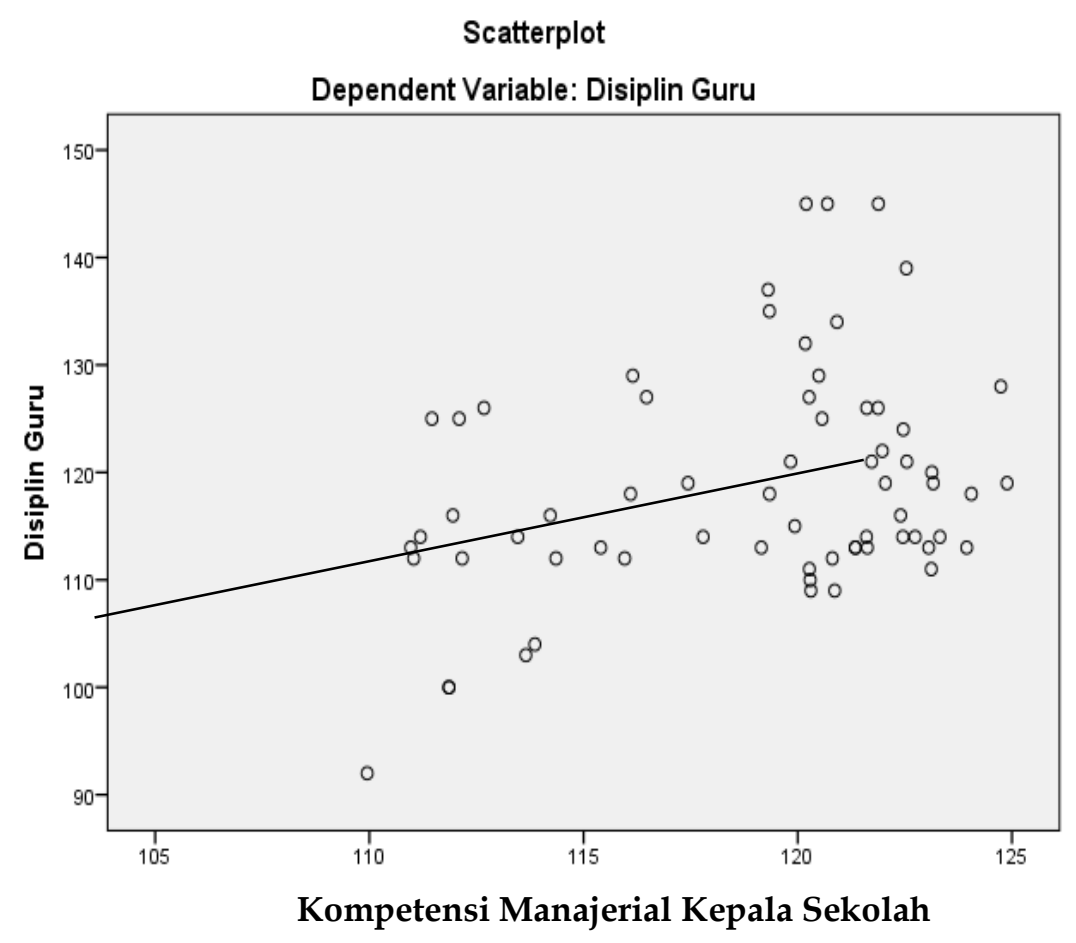

Gambar 1. Diagram Pencar Variabel $X_{1}-Y$ 
2. Pengaruh budaya kerja $\left(\mathrm{X}_{2}\right)$ terhadap disiplin guru $(\mathrm{Y})$

Ho: $\rho_{y 2}=0$ artinya tidak terdapat pengaruh positif dan signifikan budaya kerja $\left(\mathrm{X}_{2}\right)$ terhadap disiplin guru $(\mathrm{Y}) \cdot\left(\mathrm{X}_{2^{----}} \mathrm{Y}\right)$

Hi: $\rho_{y 2}>0$ artinya terdapat pengaruh positif dan signifikan budaya kerja $\left(\mathrm{X}_{2}\right)$ terhadap disiplin guru $(\mathrm{Y}) \cdot\left(\mathrm{X}_{2----} \mathrm{Y}\right)$

Tabe1 4. Kekuatan Pengaruh (Koefisien Korelasi Sederhana) $\left(\rho_{\mathrm{y} 2}\right)$ Correlations

\begin{tabular}{|ll|l|l|}
\hline & & DISIPLIN GURU & BUDAYA KERJA \\
\hline \multirow{5}{*}{ Disiplin Guru } & Pearson Correlation & 1 &, $321^{* *}$ \\
& Sig. (2-tailed) & &, 009 \\
& N & 66 & 66 \\
& Pearson Correlation &, $321^{* *}$ & 1 \\
Budaya Kerja & Sig. (2-tailed) &, 009 & \\
& N & 66 & 66 \\
\hline
\end{tabular}

${ }^{* *}$. Correlation is significant at the 0.01 level (2-tailed).

Berdasarkan tabel 4.15 tentang pengujian hipotesis $\rho_{\mathrm{y} 2}$ di atas, menunjukkan bahwa pada tingkat kepercayaan 99\% $(a=0,01)$ diperoleh koefisien korelasi sederhana Pearson correlation $\left(\rho_{\mathrm{y} 1}\right)$ adalah 0,321 dan nilai signifikansi adalah 0,009<0,05. Dengan demikian, maka Ho ditolak dan Hi diterima, yang berarti bahwa terdapat pengaruh positif dan cukup kuat serta signifikan budaya kerja terhadap disiplin guru.

Tabel 5. Besarnya Pengaruh (Koefisien Determinasi) $\left(\rho_{\mathrm{y} 2}\right)$ Model Summary ${ }^{\mathrm{b}}$

\begin{tabular}{|l|l|l|l|l|l|}
\hline Model & $\mathrm{R}$ & R Square & $\begin{array}{l}\text { Adjusted } \\
\text { Square }\end{array}$ & $\begin{array}{l}\text { Std. Error of the } \\
\text { Estimate }\end{array}$ \\
\hline 1 &, $321^{\mathrm{a}}$ &, 103 &, 089 & 10,048 \\
\hline
\end{tabular}

a. Predictors: (Constant), Budaya Kerja

b. Dependent Variable: Disiplin Guru

Adapun besarnya pengaruh ditunjukkan oleh koefisien determinasi $R^{2}(R$ square $)=0,103$, yang berarti bahwa budaya kerja memberikan 
pengaruh terhadap disiplin guru sebesar 10,3\% dan sisanya yaitu 89,7\% ditentukan oleh faktor lainnya.

Adapun arah pengaruh atau koefisien regresi sederhana disiplin guru atas budaya kerja, adalah sebagai berikut:

Tabel 6. Arah Pengaruh (Koefisien Regresi) $\left(\rho_{\mathrm{y} 2}\right)$

Coefficients $^{\mathrm{a}}$

\begin{tabular}{|c|c|c|c|c|c|c|}
\hline \multirow{2}{*}{\multicolumn{2}{|c|}{ Model }} & \multicolumn{2}{|c|}{$\begin{array}{l}\text { Unstandardized } \\
\text { Coefficients }\end{array}$} & $\begin{array}{l}\text { Standardized } \\
\text { Coefficients }\end{array}$ & \multirow[t]{2}{*}{$t$} & \multirow[t]{2}{*}{ Sig. } \\
\hline & & B & $\begin{array}{l}\text { Std. } \\
\text { Error }\end{array}$ & Beta & & \\
\hline 1 & $\begin{array}{l}\text { (Constant) } \\
\text { Budaya } \\
\text { Kerja }\end{array}$ & $\begin{array}{l}90,235 \\
, 219\end{array}$ & $\begin{array}{l}10,591 \\
, 081\end{array}$ & ,321 & $\begin{array}{l}8,520 \\
2,712\end{array}$ & ,000 \\
\hline
\end{tabular}

a. Dependent Variable:

Memperhatikan hasil analisis regresi sederhana, menunjukkan persamaan regresi sedehana (unstandardized coefficients B) $\hat{Y}=90,235+$ $0,219 X_{2}$ yang berarti bahwa setiap peningkatan satu unit skor budaya kerja akan mempengaruhi peningkatan skor disiplin guru sebesar 0,953. Adapun diagram pencar untuk variabel budaa kerja adalah sebagai berikut:

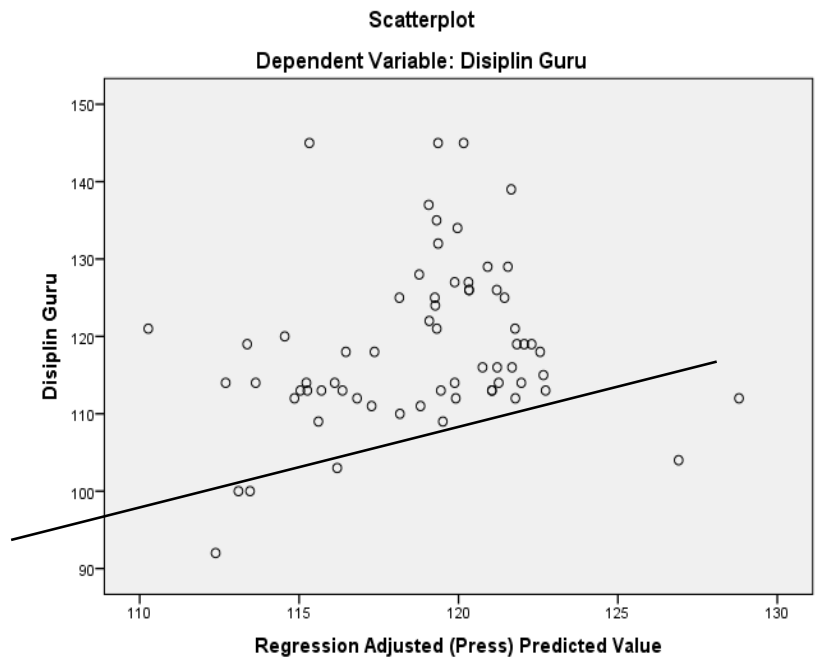

Gambar 2. Diagram Pencar Variabel $X_{2}-Y$ 
3. Pengaruh kompetensi manajerial kepala sekolah $\left(X_{1}\right)$ dan budaya kerja $\left(\mathrm{X}_{2}\right)$ secara bersama-sama terhadap disiplin guru $(\mathrm{Y})$ Ho: $R_{y \cdot 1.2}=0$ artinya tidak terdapat pengaruh positif dan signifikan kompetensi manajerial kepala sekolah $\left(\mathrm{X}_{1}\right)$ dan budaya kerja $\left(\mathrm{X}_{2}\right)$ secara bersama-sama terhadap disiplin guru $(\mathrm{Y}) .\left(\mathrm{X}_{1}, \mathrm{X}_{2^{----}}\right.$ Y)

Hi: $R_{y .1 .2}>0$ artinya terdapat pengaruh positif dan signifikan kompetensi manajerial kepala sekolah $\left(\mathrm{X}_{1}\right)$ dan budaya kerja $\left(\mathrm{X}_{2}\right)$ secara bersama-sama terhadap disiplin guru $(Y) \cdot\left(X_{1}, X_{2----}\right)$

Tabe1 7. Kekuatan Pengaruh (Koefisien Korelasi Ganda) (Ry.1.2) Model Summary ${ }^{\mathrm{b}}$

\begin{tabular}{|l|l|l|l|l|}
\hline Model & R & R Square & Adjusted R Square & \\
\hline 1 &, $470^{\mathrm{a}}$ &, 221 &, 196 & 9,439 \\
\hline
\end{tabular}

Std. Error of the Estimate

b. Dependent Variable: DISIPLIN GURU

Tabel 8. Koefisien Signifikansi ANOVA ${ }^{a}$

\begin{tabular}{|ll|l|l|l|l|l|}
\hline Model & & Sum of Squares & Df & $\begin{array}{l}\text { Mean } \\
\text { Square }\end{array}$ & F & Sig. \\
\hline \multirow{4}{*}{1} & Regression & 1591,343 & 2 & 795,672 & 8,931 &, $000^{\mathrm{b}}$ \\
& Residual & 5612,778 & 63 & 89,092 & & \\
& Total & 7204,121 & 65 & & & \\
\hline
\end{tabular}

a. Dependent Variable: DISIPLIN GURU

b. Predictors: (Constant), BUDAYA KERJA, MANAJERIAL KEPALA SEKOLAH

Berdasarkan tabel 7 dan tabel 8 tentang pengujian hipotesis $R_{y .1 .2}$ di atas, menunjukkan bahwa pada tingkat kepercayaan 99\% $(a=0,01)$ diperoleh koefisien korelasi ganda Pearson correlation $\left(\mathrm{R}_{\mathrm{y} .1 .2}\right)$ adalah 0,221 dan nilai signifikansi adalah 0,000<0,05. Dengan demikian, maka Ho ditolak dan Hi diterima, yang berarti bahwa terdapat pengaruh positif dan cukup kuat serta signifikan kompetensi manajerial kepala sekolah dan budaya kerja secara bersama-sama terhadap disiplin guru. 
Tabel 9. Besarnya Pengaruh (Koefisien Determinasi) $\left(\mathbf{R}_{\mathbf{y} 1.2}\right)$ Model Summary ${ }^{\mathrm{b}}$

\begin{tabular}{|l|l|l|l|l|}
\hline Model & R & R Square & $\begin{array}{l}\text { Adjusted R } \\
\text { Square }\end{array}$ & Std. Error of the Estimate \\
\hline 1 &, $470^{\mathrm{a}}$ &, 221 &, 196 & 9,439 \\
\hline
\end{tabular}

a. Predictors: (Constant), BUDAYA KERJA, MANAJERIAL KEPALA SEKOLAH

b. Dependent Variable: DISIPLIN GURU

Adapun besarnya pengaruh ditunjukkan oleh koefisien determinasi $\mathrm{R}^{2}(\mathrm{R}$ square $)=0,221$, yang berarti bahwa kompetensi manajerial kepala sekolah dan budaya kerja secara bersama-sama memberikan pengaruh terhadap disiplin guru sebesar 22,1\% dan sisanya yaitu 77,9\% ditentukan oleh faktor lainnya.

Adapun arah pengaruh atau koefisien regresi ganda disiplin guru atas kompetensi manajerial kepala sekolah dan budaya kerja secara bersama-sama adalah sebagai berikut:

Tabel 10. Arah Pengaruh(Koefisien Regresi Ganda) $\left(\mathbf{R}_{\mathbf{y} .1 .2}\right)$ Coefficients $^{\mathrm{a}}$

\begin{tabular}{|c|c|c|c|c|c|c|}
\hline \multirow{2}{*}{\multicolumn{2}{|c|}{ Model }} & \multicolumn{2}{|c|}{$\begin{array}{l}\text { Unstandardized } \\
\text { Coefficients }\end{array}$} & \multirow{2}{*}{$\begin{array}{l}\text { Standardize } \\
\text { d } \\
\text { Coefficients } \\
\text { Beta }\end{array}$} & \multirow[t]{2}{*}{$t$} & \multirow[t]{2}{*}{ Sig. } \\
\hline & & B & \begin{tabular}{|l} 
Std. \\
Error
\end{tabular} & & & \\
\hline \multirow{5}{*}{1} & (Constant) & 67,367 & 12,404 & & 5,431 &, 000 \\
\hline & Kompetensi & ,230 & ,074 & ,353 & 3,087 & ,003 \\
\hline & Manajerial & & & & & \\
\hline & Kepala Sekolah & & & & & \\
\hline & Budaya Kerja & ,164 & ,078 & , 240 & 2,104 & ,039 \\
\hline
\end{tabular}

a. Dependent Variable: DISIPLIN GURU

Memperhatikan hasil analisis regresi ganda, menunjukkan persamaan regresi (unstandardized coefficients B) $\hat{Y}=67,367+0,230 \mathrm{X}_{1}+$ $0,164 X_{2}$ yang berarti bahwa setiap peningkatan satu unit skor kompetensi manajerial kepala sekolah dan budaya kerja secara bersama-sama, akan mempengaruhi peningkatan skor disiplin guru sebesar 0,394 
Berdasarkan pengujian hipotesis, hasil penelitian ini menunjukkan bahwa terdapat hubungan positif, cukup kuat dan signifikan antara kompetensi manajerial kepala sekolah dengan disiplin guru di SD Islam Al-Ikhlas Cipete Jakarta Selatan, yang ditunjukkan oleh kekuatan pengaruh atau koefisien korelasi sebesar 0,408 (korelasi cukup kuat) pada taraf kepercayaan 99\% ( $a=0.01)$, sedangkan besarnya pengaruh atau koefisien determinasi $\left(\mathrm{R}^{2}\right)=0,166$, yang berarti bahwa kompetensi manajerial kepala sekolah memberikan kontribusi terhadap disiplin guru sebesar $16,6 \%$ dan sisanya yaitu $84,4 \%$ ditentukan oleh faktor lain. Sedangkan untuk arah pengaruh atau koefisien persamaan regresi sederhana $\hat{Y}=84,035+0,265 X_{1}$, yang berarti bahwa setiap peningkatan satu unit skor kompetensi manajerial kepala sekolah akan memberikan kecendrungan terhadap peningkatan skor disiplin guru sebesar 0,265

Hasil penelitian menunjukkan bahwa budaya kerja memberikan pengaruh yang cukup kuat dan signifikan terhadap disiplin guru. Hasil penilitian ini menguatkan penelitian terdahulu yang dilakukan oleh Santo Pranolo, ${ }^{29}$ yang berjudul Pengaruh Kepemimpinan dan Budaya Kerja terhadap Disiplin Kerja Guru Sekolah Dasar Negeri Di Kecamatan Telaga Antang Kabupaten Kotawaringin Timur. Hasil penelitian mengemukakan bahwa 1) kepemimpinan memberi pengaruh terhadap disiplin guru pada SDN di Kecamatan Antang, Kabupaten Kotawaringin Timur yang dijelaskan dengan t-hitung sebesar 4,472 > nilai t-tabel 2,007 dan dengan signifikansi sebesar $0,000<0,05$. 2) terdapat pengaruh antara budaya kerja terhadap disiplin kerja guru yang dijelaskan dengan t-hitung sebesar 2,675 > nilai ttabel 2,007 dan dengan signifikansi sebesar 0,010<0,05. Hal ini menunjukkan bahwa budaya kerja adalah baik dan hipotesis diterima. 3) terdapat pengaruh antara kepemimpinan dan budaya kerja guru secara

\footnotetext{
${ }^{29}$ Santo Pranolo, "Pengaruh Kepemimpinan dan Budaya Kerja terhadap Disiplin Kerja Guru Sekolah Dasar Negeri Di Kecamatan Telaga Antang Kabupaten Kotawaringin Timur," Tugas Akhir Program Magister (TAPM), Jakarta: Program Pascasarjana Universitas Terbuka, 2013
} 
bersama-sama terhadap disiplin guru d SDN Kecamatan Antang Kotawaringin Timur yang dijelaskan dengan nilai f-hitung sebesar 224,901> nilai f-tabel 3,175 dan dengan signifikansi sebesar 0,000<0,05.

Berdasarkan pengujian hipotesis, hasil penelitian ini menunjukkan bahwa terdapat hubungan positif, cukup kuat dan signifikan antara budaya kerja dengan disiplin guru di SD Islam Al-Ikhlas Cipete Jakarta Selatan, yang ditunjukkan oleh kekuatan pengaruh atau koefisien korelasi sebesar 0,321 (korelasi cukup kuat) pada taraf kepercayaan 99\% ( $\alpha=0.01$ ), sdangkan besarnya pengaruh atau koefisien determinasi $\left(R^{2}\right)=0,103$, yang berarti bahwa budaya kerja memberikan kontribusi terhadap disiplin guru sebesar 10,3\% dan sisanya yaitu 89,7\% ditentukan oleh faktor lain. Sedangkan untuk arah pengaruh atau koefisien persamaan regresi sederhana $\hat{Y}=90,235+0,219 X_{2}$, yang berarti bahwa setiap peningkatan satu unit skor budaya kerja akan memberikan kecendrungan terhadap peningkatan skor disiplin guru sebesar 0,219

Hubungan kedua variabel independen (kompetensi manajerial dan budaya kerja) secara simultan dengan disiplin guru SD Islam Al-Ikhlas Cipete Jakarta Selatan menunjukkan bahwa adanya hubungan yang positif dan signifikan

Hal ini dapat dilihat dari kekuatan atau koefisen korelasi sebesar 0,470, sedangkan koefisien determinasi atau R-square atau besarnya pengaruh 0,221 atau $22,1 \%$ dan sisanya $77,9 \%$ dipengaruhi oleh faktor lain. Adapun arah pengaruh persaman regresi $\hat{Y}=67,367+0,230 X_{1}+$ $0,164 X_{2}$ yang berarti bahwa setiap peningkatan satu unit skor kompetensi manajerial kepala sekolah dan budaya kerja secara bersama-sama mempengaruhi peningkatan skor motivasi belajar siswa sebesar 0,394

Jika dilihat dari nilai $\mathrm{R}$ square diatas maka secara bersama-sama variabel kompetensi manajerial kepala sekolah dan budaya kerja atau variabel independen memberikan kontribusi atau pengaruh sebesar 22,1\% (korelasi atau hubungan cukup kuat) terhadap disiplin guru pada SD 
Islam Al-Ikhlas Cipete jakarta Selatan bdan sisanya merupakan pengaruh faktor lain diluar kedua variabel bebas yang diteliti.

Dengan demikian, kompetensi manajerial kepala sekolah dan budaya kerja mempunyai andil yang cukup besar terhadap berjalannya disiplin guru. Sehingga sudah menjadi keharusan bagi kepala sekolah untuk senantiasa meningkatkan kompetensi manajerial dan guru agar selalu menjalankan budaya kerja yang ada di lingkunagn sekolah guna meningkatkan disiplin guru tanpa melupakan variabel atau faktor-faktor lain yang juga mempengaruhi disiplin guru. Variabel lain yang mempengaruhi disiplin guru tersebut dapat berupa pemberian kompensasi, prilaku kepemimpinan, gaya kepemimpinan, dan lain sebagainya.

\section{Kesimpulan dan saran}

Kesimpulan dari penelitian yang telah dilakukan dapat dipaparkan sebagai berikut:

1. Terdapat hubungan positif, yang cukup kuat dan signifikan antara kompetensi manajerial kepala sekolah dengan disiplin guru, yang ditunjukkan oleh koefisien korelasi sederhana (ry.1) adalah 0,408 (korelasi cukup kuat) dan koefisien determinasi $\left(\mathrm{R}^{2}\right)=0,166$, yang berarti bahwa kompetensi manajerial kepala sekolah memberikan kontribusi terhadap disiplin guru sebesar 16,6\% dan sisanya yaitu $84,4 \%$ ditentukan oleh faktor lain. Sedangkan persamaan regresi sederhana $\hat{Y}=84,035+0,265 X_{1}$, yang berarti bahwa setiap peningkatan satu unit skor kompetensi manajerial kepala sekolah akan memberikan kecendrungan terhadap peningkatan skor disiplin guru sebesar 0,265. Hubungan tersebut diperkuat dengan hasil penelitian kualitatif, yang mengungkapkan bahwa kompetensi manajerial kepala sekolah dapat memberikan sumbangan terhadap peningkatan disiplin guru. Dengan demikian, maka setiap 
peningkatan kompetensi manajerial kepala sekolah akan diikuti dengan peningkatan disiplin guru, dengan kata lain kompetensi manajerial kepala sekolah dapat memprediksi tinggi rendahnya disiplin guru.

2. Terdapat hubungan positif, cukup kuat dan signifikan antara budaya kerja dengan disiplin guru, yang ditunjukkan oleh koefisien korelasi sederhana (ry.2) adalah 0,321 (korelasi cukup kuat) dan koefisien determinasi $\left(R^{2}\right)=0,103$, yang berarti bahwa budaya kerja memberikan kontribusi terhadap disiplin guru sebesar 10,3\% dan sisanya yaitu $89,7 \%$ ditentukan oleh faktor lain. Sedangkan persamaan regresi sederhana $\hat{Y}=90,235+0,219 X_{2}$, yang berarti bahwa setiap peningkatan satu unit skor budaya kerja akan memberikan kecendrungan terhadap peningkatan skor disiplin guru sebesar 0,219. Hubungan tersebut diperkuat dengan hasil penelitian kualitatif, yang mengungkapkan bahwa budaya kerja dapat memberikan sumbangan terhadap peningkatan disiplin guru. Dengan demikian, maka setiap peningkatan budaya kerja akan diikuti dengan peningkatan disiplin guru, dengan kata lain budaya kerja dapat memprediksi tinggi rendahnya disiplin guru.

3. Terdapat hubungan positif, cukup kuat dan signifikan antara kompetensi manajerial kepala sekolah dan budaya kerja secara bersama-sama dengan disiplin guru, yang ditunjukkan oleh koefisien korelasi ganda (Ry.1.2) adalah 0,470 (korelasi cukup kuat) dan koefisien determinasi $\left(R^{2}\right)=0,221$, yang berarti bahwa kompetensi manajerial kepala sekolah dan budaya kerja secara bersama-sama memberikan kontribusi terhadap disiplin guru sebesar 22,1\% dan sisanya yaitu $77,9 \%$ ditentukan oleh faktor lain. Sedangkan persamaan regresi ganda $\hat{Y}=67,367+0,230 X_{1}+0,164 X_{2}$, yang berarti bahwa setiap peningkatan satu unit skor kompetensi manajerial kepala sekolah dan budaya kerja secara bersama-sama akan 
memberikan kecendrungan terhadap peningkatan skor disiplin guru sebesar 0,394. Hubungan tersebut diperkuat dengan hasil penelitian kualitatif, yang mengungkapkan bahwa kompetensi manajerial kepala sekolah dan budaya kerja secara bersama-sama dapat memberikan sumbangan terhadap peningkatan disiplin guru. Dengan demikian, maka setiap peningkatan kompetensi manajerial kepala sekolah dan budaya kerja secara bersama-sama akan diikuti dengan peningkatan disiplin guru, dengan kata lain kompetensi manajerial kepala sekolah dan budaya kerja secara bersama-sama dapat memprediksi tinggi rendahnya disiplin guru.

\section{Saran}

Berdasarkan pembahasan hasil penelitian serta kesimpulan sebagaimana yang telah dikemukakan di atas, maka disampaikan saran-saran sebagai berikut:

1. Kepada para guru hendaknya menjaga dan mempertahankan disiplin yang telah terlaksana, dan kepala sekolah hendaknya lebih tegas dalam menindaklanjuti jika terjadi pelanggaran disiplin dari para guru sehingga proses pembelajaran dapat berjalan dengan lancar.

2. Sebagaimana hasil penelitian yang mempunyai jumlah persentase cenderung cukup tinggi, kepala sekolah harus tetap mempertahankan kompetensi manajerialnya bahkan meningkatkan tidak hanya dalam kompetensi manajerialnya saja tetapi memiliki seluruh kompetensi yang lain, seperti kompetensi kepribadian, kompetensi sosial, kompetensi supervisi dan kompetensi kewirausahaan

3. Kepala sekolah dan para guru hendaknya dapat memelihara bahkan meningkatkan budaya kerja yang baik, agar tercipta lingkungan 
kerja yang kondusif, aman, tentram sehingga menganggap tempat kerja sebagai rumah sendiri.

4. Kepada peneliti selanjutnya agar meneliti dalam jumlah sampel yang lebih banyak (sekolah satu kecamatan/kota), sehingga hasil penelitian dapat digeneralisasikan kepada sekolah/madrasah lainnya.

\section{Daftar Pustaka}

Amaliyah, Fisqy Kayyasah., 2017, “Pengaruh Motivasi Kerja dan Disiplin Kerja Terhadap Kinerja Guru Yayasan Swadhipa Natar TP 2015/2016. Tesis. Bandar Lampung: Pascasarjana Universitas Lampung.

Asmani, Jamal Ma'mur., 2012, Tips Menjadi Kepala Sekolah Profesional, Yogyakarta: Diva Press.

Badudu, J.S., 2003, Kamus Kata-kata Serapan Asing dalam Bahasa Indonesia, Jakarta: Kompas.

Budiono., Kamus Lengkap Bahasa Indonesia, Jakarta: Bintang Indonesia.

Danim, Sudarwan., 2007, Visi Baru Manajemen Sekolah: Dari Unit Birokrasi ke Lembaga Akademik. Jakarta: Bumi Aksara.

Darmadi. Membangun Paradigma Baru Kinerja Guru. Bogor: Guepedia Publisher.

Dewi, Rina Puspita., 2008, Modul: Menjaga dan Melindungi Budaya Kerja Sesuai Standar Isi 2006. Jakarta: Yudhistira.

Fridani, Lara., 2013, Inspiring Education-Usia Sd (True Storie). Jakarta: PT. Elex Media Komputindo.

Hidayah, Nur., 2015, “Pengaruh Kepemimpinan Kepala Madrasah dan Kecerdasan Emosional Terhadap Disiplin Kerja Guru Di Madrasah Ibtidaiyah Pembangunan UIN Jakarta". Tesis. Jakarta: Pascasarjana Institut PTIQ Jakarta.

Isyandi et al., 2014, "Pengaruh kepemimpinan, Budaya Kerja, Lingkungan Kerja Terhadap Disiplin Kerja dan Kinerja Personil Polda Riau." dalam Jurnal Tepak Manajemen Bisnis. Vol. 06 No. 02. 
Mariono et al., 2008, Manajemen dan Kepemimpinan Pendidikan Islam. Bandung: PT Refika Aditama.

Muchson, M. Statistik Deskriptif. Tuban: Spasi Media.

Mulyasa., 2013, Implementasi Kurikulum Satuan Pendidikan Kemandirian Guru dan Kepala Sekolah. Jakarta: Remaja Rosdakarya.

Mustari, Mohamad., 2015, Manajemen Pendidikan. Jakarta: PT. Raja Grafindo Persada.

Poerwodarminto, W. J. S., 2006, Kamus Umum Bahasa Indonesia. jakarta: Balai Pustaka.

Pranolo, Santo., 2013, "Pengaruh Kepemimpinan dan Budaya Kerja terhadap Disiplin Kerja Guru Sekolah Dasar Negeri Di Kecamatan Telaga Antang Kabupaten Kotawaringin Timur". Tugas Akhir Program Magister (TAPM). Jakarta: Program Pascasarjana Universitas Terbuka.

Priansa, Doni Juni dan Somad, Rismi., 2014, Manajemen Supervisi dan Kepemimpinan Kepala Sekolah. Bandung: Alfabeta.

Purwanto, Johanes., 2017, “Upaya Meningkatkan Disiplin Guru Dalam Kehadiran Menagajar di Kelas Melalui Reward dan Punishment DI SDN Bandulan 1 Kecamatan Sukun Malang, " dalam Jurnal Bidang Pendidikan Dasar (JBPD). Vol. 1 No. 02.

Rahman, Masykur Arif. Kesalahan-Kesalahan Fatal Paling Sering Dilakukan Guru Dalam Kegiatan Belajar Mengajar. Yogyakarta: Diva Perss. 2011

Ramayulis., 2008, Ilmu Pendidikan Islam. Jakarta: Bumi Aksara. Cetakan ke3.

Sari, Nia dan Wardani, Ratna., 2015, Pengolahan dan Analisis Data Statistika dengan SPSS. Yogyakarta: Deepublish.

Siagian, Sondang P., 2004, Manajemen Sumber Daya Manusia. Jakarta: Bumi Aksara.

Silalahi, Ulbert., 2002, Studi tentang Ilmu Administrasi. Bandung: Sinar Baru Algensindo.

Soegoto, Eddy Soeryanto., 2008, Marketing Reserch (The Smart Way to Solve a Problem). Jakarta: Elex Media Komputindo. 
Lia Riyani

Sugiyono., 2013, Metode Penelitian Pendidikan Pendekatan Kuantitatif, Kualitatif, dan $R \mathcal{E}$ D. Bandung: Alfabeta.

Sutopo, Yeri dan Slamet, Achmad. Statistika Inferensial. Yogyakarta: Penerbit Andi.

Tilaar, Har., 2000, Paradigma Baru Pendidikan Nasional. Jakarta: Rineka Cipta.

Tjo, Ellys. 2013, Kompetensi Guru-guru Efektif. Jakarta : Permata Puri Media.

Zainarti., 2014, “Manajemen Islam Perspektif Al-Qur'an," dalam Jurnal Iqra'. Vol. 08 No. 01. 